\title{
Epimenides' Tale of the Birth of Zeus
}

\author{
Elwira Kaczyńska \\ (University of Łódź)
}

\begin{abstract}
It is suggested that Epimenides of Crete, a well-known Greek prophet, poet and politician (7th6th century BC), placed Zeus' birthplace near the Cretan city of Arcadia (now Arkalochori). Callimachus' Hymn to Zeus seems to have been modelled on Epimenides' version of the birthstory of the principal god. It not only contains an exact imitation of the prophet's words "the

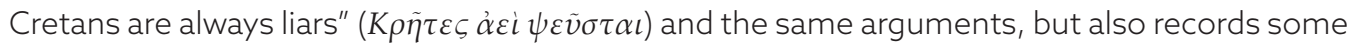
of Epimenides' aetiological tales, e.g. on the Omphalian plain and the Mountain Panacra. Callimachus of Cyrene partially changed the original legend of Zeus' birth, transferring Arcadia from Crete to Peloponnese. However, some contradictions and inconsistencies which appear in Callimachus' Hymn to Zeus provide credible evidence for establishing Epimenides' version of the myth.
\end{abstract}

\section{Keywords}

Callimachus of Cyrene; Epimenides of Crete; Zeus' birth tale

In the Hymn to Zeus the prominent Alexandrian poet Callimachus of Cyrene deals with the issue of the birth of the youngest son of Cronus and presents the controversy surrounding it by referring to the statements of former Greek authors (lines 4-9):

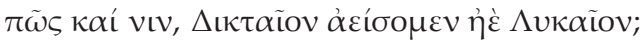

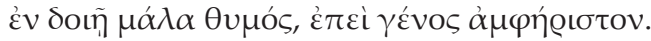

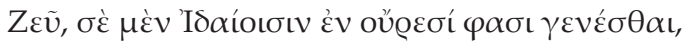

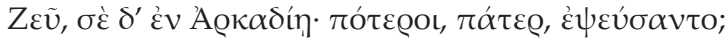

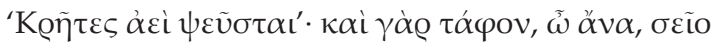

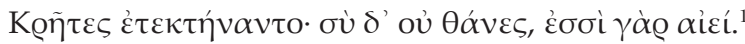

"How shall we sing of him - as lord of Dicte or of Lycaeum? My soul is all in doubt, since debated is his birth. O Zeus, some say that thou wert born on the hills of Ida; others, O Zeus, say in Arcadia; did these or those, O Father, lie? 'Cretans are ever liars.' Yea,

1 Stephens (2015: p. 52). See also Kallimachos (2010: p. 52). 
a tomb, O Lord, for thee the Cretans builded; but thou didst not die, for thou art for ever." [Transl. A. W. Mair 1989: p. 37].²

Callimachus does not follow the popular record by Hesiod, who tells that the birth of Zeus has taken place in the Aigaion Mountains in the vicinity of the Cretan city of Lyctus, and he actually omits the Hesiodean version altogether. Instead he indicates other possible locations:

a) in the Dictaean Mountains (on Crete);

b) in the Idaean Mountains;

c) on Mount Lykaion (in the Peloponnese);

d) in Arcadia.

At present we are unable to unequivocally determine the sources used by Callimachus which led him to enunciate the aforementioned versions, since the poet of Cyrene does not cite any names. Likewise, the anonymous author of the Homeric Hymn to Dionysus does not give any hint either ${ }^{3}$, when he introduces the problematic issue of Zeus' son's birth (line 1-9):

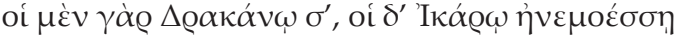

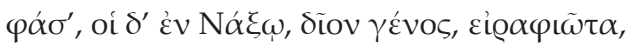

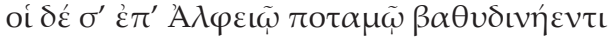

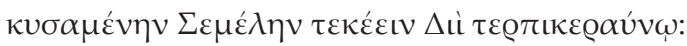

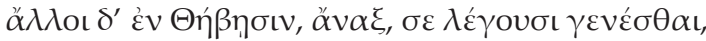

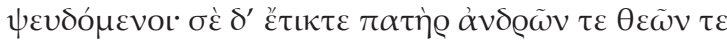

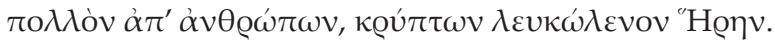

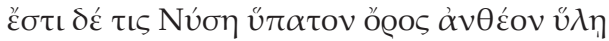

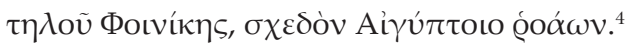

"For some say, at Dracanum; and some, on windy Icarus; and some, in Naxos, O Heavenborn, Insewn; and others by the deep-eddying river Alpheus that pregnant Semele bare you to Zeus the thunder-lover. And others yet, lord, say you were born in Thebes; but all these lie. The Father of men and gods gave you birth remote from men and secretly from white-armed Hera. There is a certain Nysa, a mountain most high and richly grown with woods, far off in Phoenice, near the streams of Aegyptus." [Transl. H. G. Evelyn-White]. ${ }^{5}$

2 Different English translations are published in the following works: Lombardo \& Ross (1988: p. 3); Stephens (2015: p. 55).

3 Depew (1993: p. 73) stresses that "these lines [of Callimachus' Hymn to Zeus] are modeled on the extant opening lines of the first Homeric Hymn (to Dionysus)". A similar opinion had earlier been expressed by Steffen (1984: p. 469: "Multo propius Callimachi locus ad hymnum Homericum in Bacchum accedit"), as well as by Hopkinson (1984: p. 140).

4 Càssola (1994: p. 18). See also Allen, Halliday \& Sikes (1980: p. 1).

5 Evelyn-White (1920: p. 287). 
The position of the main informant of Callimachus and the intercessor of tradition might be attributed to Epimenides of Crete (7th-6th century BC), ${ }^{6}$ the only writer known by name who addresses the subject of descent and genealogy of the gods during the period between Hesiod and Callimachus. The titles of his poetic disquisitions which could have

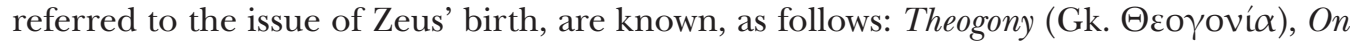

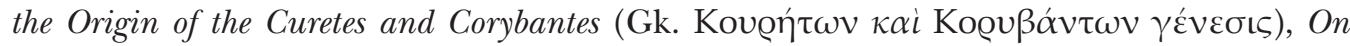

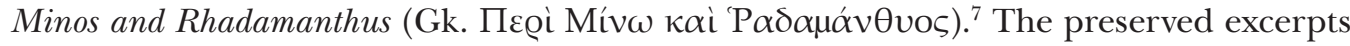
of Epimenides' poems indicate that the Cretan author frequently polemicizes against Hesiod and follows a different tradition compared with the Boeotian poet. Thus Epimenides gives uncommon genealogies of Aphrodite, Erinyes, Moirai and Pan, which are completely different from those of Hesiod. ${ }^{8}$ Arguably, with reference to the birthplace of Zeus, Epimenides takes a stand which is contrary to the Hesiodean version.

Just as Epimenides both imitated and criticized Hesiod, Callimachus also benefited profusely from the output of the Cretan poet. In the above excerpt from the Hymn to

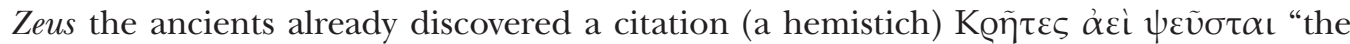
Cretans are always liars"9 derived supposedly from Epimenides' Theogony.

The ancient testimonies leave no doubt about this relationship. The Apostle Paul reports in The Letter to Titus (I 12) that "one of them, a prophet of their own, said,

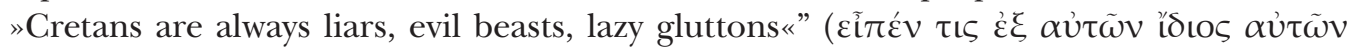

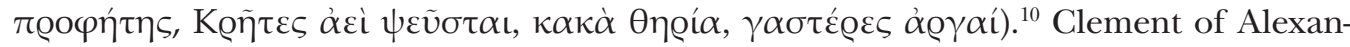
dria identifies the pagan seer with Epimenides, quoting Saint Paul's full hexameter. Saint Jerome does the same, but signalizes at the same time that Callimachus made use of Epimenides' initial hemistich (Epimenides ... cuius heroici hemistichium postea Callimachus usurpavit). ${ }^{11}$ Callimachus' imitation must have been thoroughly deliberate. At this point, it is worth stressing that on the other hand the Cretan poet paraphrases Hesiod. It is

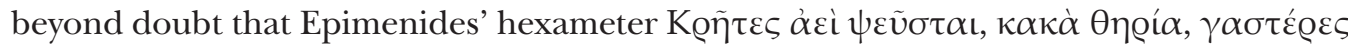

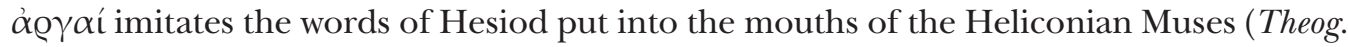

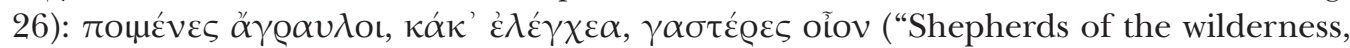
wretched things of shame, mere bellies"). ${ }^{12}$

6 D’Alessio (1996: p. 66); Cuypers (2004: pp. 102-105).

7 According to Diogenes Laertios (I, 111-112), Epimenides of Crete composed several epic works of consid-

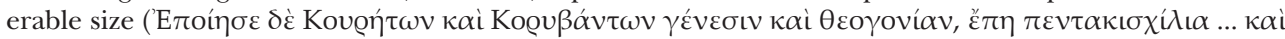

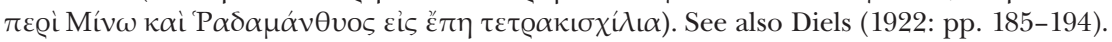

8 Appel (1984: pp. 224-225). Note that Epimenides believes that Air and Night appeared in the beginning of the world, whereas Hesiod's cosmogonic idea is different: the ancestors of all the creation were Chaos, Gaia and Eros.

9 See Demoulin (1901: p. 81); West (1983: pp. 47-48); Hopkinson (1994: p. 123); Papathanasopoulos (1996: p. 27); Stephens (2015: p. 58), Żybert-Pruchnicka (2016: p. 113). The ancient opinion on the Cretans as fanatic liars is carefully reviewed by Kaczyńska (2000b: pp. 528-534), as well as by Vertoudakis (2000: pp. 106-113).

10 See Howell (1964: pp. 7-29).

11 Rendel Harris (1906: pp. 305-317).

12 Translated into English by H. G. Evelyn-White (1920: pp. 80-81). 
The mutual relations between Hesiod, Epimenides and Callimachus are undoubtedly more profound than the aforementioned testimonies suggest. Normally, two Syriac commentaries on The Acts of the Apostles are being overlooked, even though they make a significant contribution to the documentation of those mutual connections, especially to the reconstruction of the lost works of Epimenides. The former commentary was composed about the year 850 C.E. by Ishodad of Merv, the Nestorian Church Father, and the latter under the title Gannat Busame ("Garden of Delights") remained anonymous. Both of them contain many extracts adopted from the works of Theodore of Mopsuestia (died 428 C.E.), known commonly as "The Interpreter". ${ }^{13}$

The work Gannat Busame gives the following commentary:

„In Him we live and move and have our being. The Cretans used to say of Zeus, that he was a prince and was ripped up by a wild boar, and he was buried: and Io! his grave is with us. Accordingly Minos, the son of Zeus, made over him a panegyric and in it he said: »A grave have fashioned for thee, $\mathrm{O}$ holy and high One, the lying Cretans, who are the time liars, evil beasts, idle bellies; but thou diest not, for to eternity thou livest, and standest; for in thee we live and have our being «". [Transl. J. Rendel Harris]. ${ }^{14}$

Ishodad of Merv delivers similar but slightly more elaborate information, invoking the authority of "The Interpreter" and commenting on The Acts of the Apostles (XVII 28) as follows: ${ }^{15}$

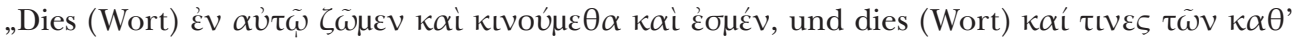

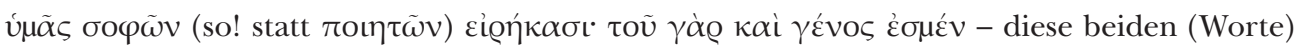
hat Paulus von gewissen heidnischen Poeten zitiert. Inbetreff dieses (Wortes) aber $\dot{\varepsilon} v \alpha \hat{v} \tau \tilde{\omega}$ $\zeta \tilde{\omega} \mu \varepsilon v$ ktl. (ist zu bemerken): Weil die Kreter als Wahrheit über Zeus aussagten, daß er ,ein Tyrann war, daß er von einem Wildschwein zerrissen und begraben wurde, und siehe sein Grab ist bei uns bekannt', deshalb machte Minos, der Sohn des Zeus, für seinen Vater eine Lobrede ( $\dot{\gamma} \gamma \kappa \omega \dot{\omega} \mu \nu)$ und sagte darin:

'Ein Grab fertigten für dich, o Heiliger und Erhabener, die lügnerischen Kreter, die bösen Tiere und faulen Bäuche, denn du bist nimmermehr tot, lebendig bist du und bleibend, denn in dir leben und weben und sind wir'. ${ }^{16}$ Also aus dem Minos zitierte der selige Paulus das Wort. Jenes (Wort) hinwiederum aber غ̇k

13 Rendel Harris (1906: p. 310).

14 Ibidem.

15 The German translation is given by Greßmann (1913: pp. 936-937). The Syriac text, as well as an English version, can be found in Dunlop Gibson (1913/2011: p. 39). The English translation are also cited by Rendel Harris (1912: pp. 348-353), and Cook (1914: pp. 663-664, fn. 2).

16 The English translation, proposed by Dunlop Gibson (1913/2011: p. 39), runs as follows: "The Cretans fashioned a tomb for Thee, O Holy and High!, liars, evil beasts, idle bellies, for Thou diest not; for ever Thou livest and standest; for in Thee we live and move and have our being”. A similar version, introduced by J. Rendel Harris, is quoted by Hutchinson (1963: p. 200), as well as by Davaras (1989: p. 347). 


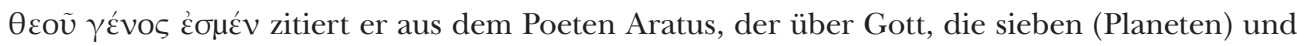
die zwölf (Tierkreiszeichnen) schrieb: 'Von Gott beginnen wir, von dem Gott des Himmels, das ist Zeus. Denn erfllt mit seinem Namen sind alle Märkte, Seen, Häfen, und auch überall bedürfen wir seiner, weil wir seines Geschlechtes sind. Und er in seiner Freundlichkeit gibt gute Zeichen uns und allen Menschen. Er treibt uns, uns dem Werk zu nahen, und er ordnet alles Sichtbare und alles Unsichtbare. Deswegen dienen wir alle ihm und sprechen: Heil dir, unser Vater, wundervoll und groß!'. Und auch Plato und die anderen sagen, daß die Seelen göttlicher Natur seien". [Transl. H. Greßmann].

Since the commentator translates Aratus' prooimion ( $P h .5 f f$.$) correctly into the Syriac$ language (only the end of the quotation is rendered more freely), it should be accepted that the translation of Minos' utterance reflects the original fairly accurately. The second line of the quatrain unquestionably corresponds to the renowned Epimenides' hexameter, which proves that the whole utterance of Minos should be ascribed to him. There are two attempts at the reconstruction of the Greek version on the base of two almost identical Syrian commentaries. The first solution has been proposed by J. Rendel Harris: ${ }^{17}$

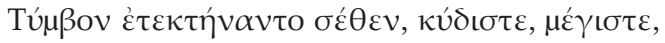

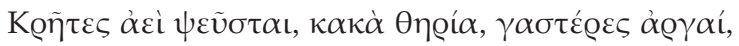

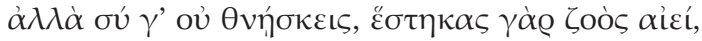

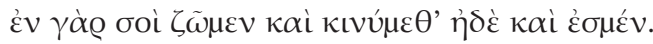

Striving to enhance the suggested version, A. B. Cook offered a different reconstruction: ${ }^{18}$

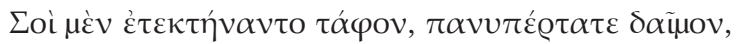

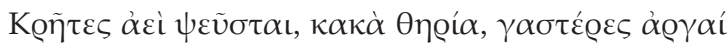

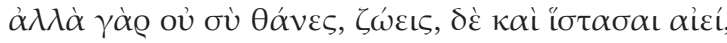

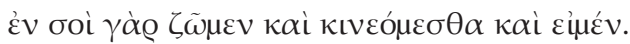

It is worth emphasizing that two lines (the second and the fourth one) have been recorded independently in Greek texts and thus their authenticity does not arouse suspicion. The first and the third line are more or less credible extrapolations. In any case, the general sense of Epimenides' quatrain stays fairly clear. The author puts the words into the mouth of Minos, Zeus' son. This is also the case in Hesiod's Theogony, where the paragraph imitated by Epimenides comprises the utterance on the Heliconian Muses (Theog. 26-28): ${ }^{19}$

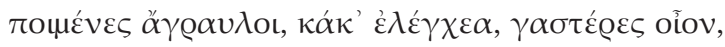

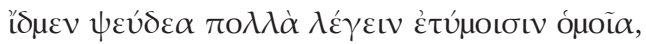

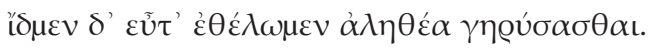

17 Rendel Harris (1906: pp. 305-317). See also Nicklin (1916: pp. 33-37); Powell (1916: pp. 139-142); Howell (1964: pp. 19, 23).

18 Cook (1914: p. 664, fn. 1).

19 Colonna (1983: p. 60). See also Leclerc (1992: pp. 221-233); Podbielski (1994: p. 178). 
"Shepherds of the wilderness, wretched things of shame, mere bellies, we know how to speak many false things as though they were true; but we know, when we will, to utter true things." ${ }^{20}$

Comparing Epimenides' quatrain with Callimachus' text, it should be evident that the

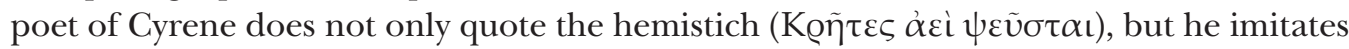
most of the statements given by Epimenides as well. Both poets display a number of shared elements, whose coincidence cannot be random. They both:

1) accuse the Cretans of falsehood;

2) consider the grave of Zeus erected on the island of Crete to be the main reason for the prevailing opinion of Cretans' inveracity; ${ }^{21}$

3) deny the rumours about the alleged death of Zeus;

4) stress the immortality of Zeus;

5) polemicize with different traditions invoking the authority of either a god (Zeus in Callimachus) or a hero (Minos in Epimenides).

It is worth highlighting that Callimachus' polemic is preceded by the controversy bearing considerable resemblance to the dissent presented in the Homeric Hymn to Dionysus. It seems that Epimenides' polemic also commenced with a similar enumeration. The poet of Crete could have considered both Hesiod's Theogony and the local Cretan legends. In fact, he could have considered various options and then advocated one of the Cretan versions supported by the authority of mythical Minos. There are four possibilities taken into consideration: the Aigaion Mountains, the Dictaean Mountains, the Idaean Mountains or the Cretan city of Arcadia, whose existence is mentioned in numerous ancient sources. ${ }^{22}$

The dispute over the location of Cretan Arcadia has not been unambiguously settled so far, but it lay most likely on the premises of today's Arkalochori, ${ }^{23}$ where the bygone ritual cave was situated. ${ }^{24}$ As opposed to the other Cretan ritual caves, the cave in Arkalochori was teeming with the items of military nature (i.e. swords, spears, shields, daggers, hatchets), which connotes the myth about Zeus' upbringing by the dancing people of the well-armed Curetes. ${ }^{25}$ Epimenides was supposedly the first person to describe the Curetes, inasmuch as Diogenes Laertius mentions his poem On the Origin of the Curetes

20 Translated by H. G. Evelyn-White (1920: pp. 80-81).

21 The problem of Zeus' tomb in Crete is broadly discussed by Kaczyńska (2002: pp. 83-107).

22 For the ancient evidence on the Cretan city of Arcadia (or Arcades), see Guarducci (1935: pp. 6-7); Kitchell (1977: pp. 266-280).

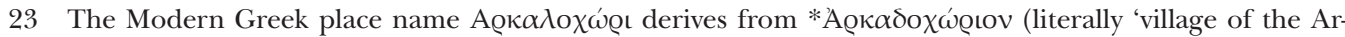

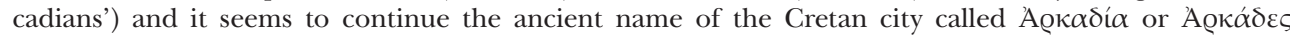
(Kaczyńska 1997: p. 37, fn. 16). The same location of the ancient city of Arcadia is suggested by Witczak

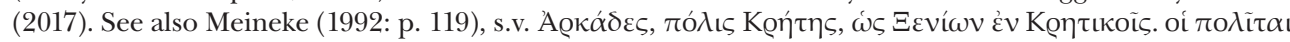

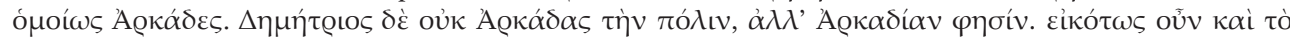

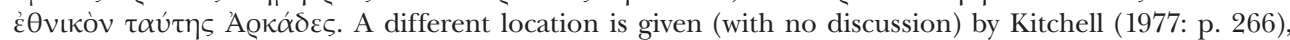
and Vasilakis (2000: pp. 72-73). The Greek historian Spanakis (1991: p. 143) emphasizes that the location of Arkadia is ambiguous ("H $\theta \varepsilon \dot{\sigma} \sigma \eta \tau\rceil \varsigma \alpha \mu \varphi \iota \sigma \beta \eta \tau \varepsilon i ́ \tau \alpha$ ”).

24 See Hazzidakis \& Bambakas (1912-1913, pp. 35-47); Marinatos (1962: pp. 87-94); Faure (1964: pp. 160162; 1996: pp. 72-74); Rutkowski \& Nowicki (1996: pp. 24-26). 
and Corybantes. ${ }^{26}$ From an archeological point of view, the cave in Arkalochori perfectly corresponds to the legend of Zeus being under the care of the armed Curetes. Therefore, one can hypothesize that Epimenides located Zeus' birthplace in Cretan Arcadia.

Callimachus refers, as was stated above, very thoroughly to the work of Epimenides, but disagrees with him on a very fundamental issue. For he transfers Arcadia from Crete to the Peloponnese and thereby is the first, as researchers emphasize, to relocate Zeus' birthplace from the island to the mainland. Already long ago scholars pointed to the motives by which the poet of Cyrene was driven. Callimachus inclines towards the relocation because of the age's literary tendencies which are: (A) the intention to surprise and astound the audience; (B) the attempt at avoiding the widely known versions of the myth; (C) the endeavour to show off his erudition; (D) a need to make use of his own research into the Peloponnesian Arcadia.

My aim is thus to prove that in the Callimachean description of Arcadia there exist such elements that do not conform to the description of Peloponnesian Arcadia and at the same time match the characterization of the Cretan city of Arcadia.

(1) At the moment of Zeus' birth, Arcadia is devoid of any rivers. ${ }^{27}$ Vainly searching for water to rinse herself and the divine infant, Rhea addresses Gaia to make a request for the initiation of a brook. As a result of the stroke of a sceptre, thanks to the goddess of earth, the salutary water spurts from the rock (lines 10-32). This incoherence consists, among other things, in Callimachus contradicting himself by enumerating the rivers of Peloponnesian Arcadia and avoiding the anachronism by means of the assertion that those were the subterranean rivers. In fact, it was the Cretan Arcadia that was poorly irrigated and even cyclically deprived of any water. ${ }^{28}$ Both Pliny the Elder ${ }^{29}$ and Seneca the Younger (invoking the famous Greek writer Theophrastus of Eresos) ) $^{30}$ inform about it.

(2) The reader might be bewildered by the sudden and unexpected transfer of the action from the Peloponnese to Crete. ${ }^{31}$ The lines 37-41, containing the aetiological

26 See above, footnote 7.

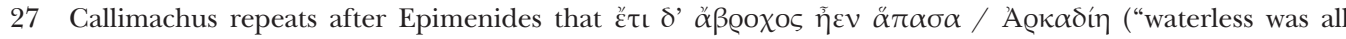

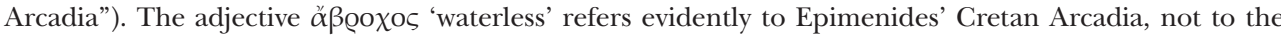
Peloponnesian Arcadia.

28 See especially Strataridaki, Chalkiadakis \& Ioannidou (2006: pp. 180-190).

29 Plin., Nat. XXXI 30: Proditur certe in Creta expugnato oppido, quod vocabatur Arcadia, cesasse fontes amnesque, qui in eo situ multi erant, rursus condito post sex annos emersisse, ut quaeque coepissent partes coli. "It is at any rate reported that in Crete, when a town called Arcadia had been stormed, the many springs and rivers of that region went dry, and six years afterwards, when the town was rebuilt, they reappeared, as each piece of land came under cultivation." [Transl. Jones 1963].

30 Sen., Nat. III 11.5: Idem (i.e. Theophrastus) ait circa Arcadiam, quae urbs in Creta insula fuit, fontes et rivos substitisse, quia desierit coli terra, diruta urbe: postea vero quam cultores receperit, aquas quoque recepisse. Causam siccitatis hanc ponit, quod obduruerit constricta tellus, nec potuerit imbres inagitata transmittere. "Theophrastus says that around Arcadia, which was a city on the island of Crete, fountains and rivers ceased to exist because the earth ceased to be cultivated after the city was destroyed; but after the earth got back its cultivators, it also recovered its waters. He proposed this reason for the dryness: namely, that the constricted earth became hard and while it was not being stirred it was unable to transmit rainwaters." [Transl. Corcoran 1971: pp. 226-229].

31 McLennan comments on the place-transferring as follows: "The scene changes immediately to Crete, without any link passage, not even a connecting particle” (McLennan 1977: p. 74). According to Stephens 
justification of the name of the Neda river, place the action in Arcadia (i.e. the central region of the Peloponnese). The next passage (lines 42-45) commences at a time when the nymph Neda, carrying little Zeus, is leaving the Cretan city of Thenai, passing the Omphalian Plain and heading in the direction of Knossos. That situation would not be astonishing if Epimenides actually had located the aforementioned Arcadia on Crete.

(3) The location of the Omphalian Plain and the city of Thenai used to cause and still causes a lot of trouble for the editors and commentators of the Callimachean Hymn to Zeus. ${ }^{32}$ Battiada's description is clearly misleading because neither Thenai, nor the Omphalian Plain are situated between the Peloponnesian Arcadia and Knossos. A scientific objection was raised against the fact that the nymph Neda, who was ordered by Rhea to bring the newborn child to Crete, arrives in Thenai earlier than in Knossos, although it would have been more logical to reverse the order of the visited cities. ${ }^{33}$ The location of Thenai and the Omphalian Plain would be correctly determined, provided we assume that Callimachus used the description referring to the relationship of those places to the Cretan Arcadia, since both of them are located south-eastwards of Knossos, precisely by the former Minoan road from the Cretan Arcadia (currently Arkalochori) to Knossos. ${ }^{34}$ The Omphalian Plain is also mentioned by Diodorus Siculus, ${ }^{35}$ who states, summarizing Epimenides' record, that the infant Zeus was at that time being carried by the Curetes, thus the poet of Cyrene clearly misrepresented and modernized the version introduced by the Cretan poet.

(4) Scholars accord on Callimachus' ignorance of the geography of Crete, ${ }^{36}$ but it had to be pointed out that he provides a great number of credible and unknown topographic details. Who else could have possibly been a better informer than the native Cretan - Epimenides?

(5) The myth about Zeus' upbringing was treated concisely by Callimachus, even though there are some elements not congruent to any other ancient testimony in his record (i.a. Mount Panacra, ${ }^{37}$ the bee Panacris nurturing the divine infant). ${ }^{38}$ The legend must have been adopted by Callimachus because the Alexandrian manner demanded the well-known myths to be treated laconically. It seems likely that the poet of Cyrene actually encapsulated Epimenides.

There are five premises enumerated in the article that signalize the adoption of some elements from Epimenides, which are incoherent in relation to the Peloponnesian ver-

(2015: p. 55), the lines 42-45 of the Callimachean Hymn to Zeus "create a moment of disorientation for the reader: suddenly, we are no longer in Arcadia". It is necessary to explain that this observation refers to "the Peloponnesian Arcadia". The Cretan city of Arcadia in Epimenides' work causes no disorientation.

Griffiths (1970: pp. 32-33).

Cf. Griffiths (1970: pp. 32-33); Tandy (1979: pp. 115-119).

See especially Kaczyńska (2000a: pp. 101-111).

Oldfather (1970: p. 286).

36 It is worth emphasizing that Horowski (1967: pp. 137-138) mentions an example of ignorance of the Cretan realities in Callimachus' Hymnus to Artemis (lines 189-199). In another place the Polish philologist says: "A number of Callimachus' data on Cretan cities are inaccurate" (Horowski 1967: p. 197). Cf. also Kaczyńska (2000a: p. 106).

37 Tandy (1979: pp. 128-129); Fernández-Galiano (1980: p. 511); Kaczyńska (1999a: pp. 33-37; 1999b: pp. 11-14); Sistakou (2005: pp. 96, 338).

38 Horowski (1967: p. 139); Fernández-Galiano (1980: p. 511); Kaczyńska (1999b: pp. 12-13). 
sion, in the Callimachean Hymn to Zeus. From the consideration presented the following conclusion can be drawn: Epimenides wrote supposedly about the Cretan Arcadia (currently Arkalochori) as a place of Zeus' birth. Callimachus benefited greatly from the works of his predecessor by imitating him, and by summarizing and reformulating his writings in accordance with the requirements of Alexandrian poetics.

\section{Bibliography}

Allen, Th. W., Halliday, W. R., \& Sikes, E. E. (Eds.). (1980). The Homeric Hymns. Amsterdam: A. M. Hakkert.

Appel, W. (1984). Epimenides. Filomata, 362, 221-230.

Càssola, F. (1994). Inni omerici. Milano: A. Mondadori Editore.

Colonna, A. (1983). Esiodo, Opere. Teogonia - Catalogo delle donne - Opere e giorni - Poemetti pseudo-esiodei. Milano: Editori Associati S.p.A.

Cook, A. B. (1914). Zeus: A Study in Ancient Religion (Vol. I). Cambridge: Cambridge University Press.

Corcoran, T. H. (1971). Seneca the Younger, Natural Questions (Vol. I). London-Cambridge: Harvard University Press.

Cuypers, M. (2004). Prince and Principle: The Philosophy of Callimachus' Hymn to Zeus. In M. A. Harder, R. F. Regtuit, \& G. C. Wakker (Eds.), Beyond the Canon. Groningen Workshop on Hellenistic Poetry (Vol. 7; Hellenistica Groningiana, 11, pp. 95-116). Leuven: Peeters.

D’Alessio, G. B. (1996). Callimaco: Inni, Epigrammi, Ecale (Vol. I). Milano: Biblioteca Universale Rizzoli.

Davaras, C. (1989). Guide to Cretan Antiquities. Athens: Eftalofos S.A.

Demoulin, H. (1901). Épiménide de Crète (Bibliothèque de la Faculté de Philosophie et Lettres de l'Université de Liège, 12). Bruxelles: Sté Belge de Librairie.

Depew, M. (1993). Mimesis and Aetiology in Callimachus's Hymns. In M. A. Harder, R. F. Regtuit, \& G. C. Wakker (Eds.), Callimachus. Groningen Workshop on Hellenistic Poetry (Vol. 1; Hellenistica Groningiana, 1; pp. 57-77). Groningen: E. Forsten.

Diels, H. (Ed.). (1922). Die Fragmente der Vorsokratiker: griechisch und deutsch (Vol. II, 4. ed.). Berlin: Weidmann.

Dietrich, B. C. (1974). The Origins of Greek Religion. Berlin-New York: W. de Gruyter.

Dunlop Gibson, M. (Ed.). (1913/2011). The Commentaries of Isho'dad of Merv, Bishop of Hadatha (c. 850 A.D.) in Syriac and English, Vol. IV: Acts of the Apostles and three Catholic Epistles in Syriac and English. Cambridge: Cambridge University Press.

Evelyn-White, H. G. (1920). Hesiod: The Homeric Hymns and Homerica. London: W. Heinemann; New York: G. P. Putnam's Sons.

Faure, P. (1964). Fonctions des cavernes crétoises. Paris: Éditions de E. Boccard.

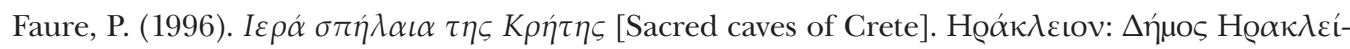

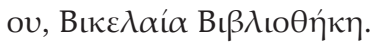

Fernández-Galiano, E. (1980). Léxico de los himnos de Calimaco (Vol. IV). Madrid: Consejo Superior de Investigaciones Científicas.

Greßmann, H. (1913). Review of Dunlop Gibson (1913). Berliner philologische Wochenschrift, 33, 936-939. 
Griffiths, A. H. (1970). Six Passages in Callimachus and the Anthology. Bulletin of the Institute of Classical Studies of the University of London, 17, 32-43.

Guarducci, M. (Ed.). (1935). Inscriptiones Creticae opera et consilio Friderici Halbherr collectae, Vol. I: Tituli Cretae mediae praeter Gortynios. Roma: La Libreria dello Stato.

Hazzidakis, J., \& Bambakas, J. (1912-1913). An Early Minoan Sacred Cave at Arkalochori in Crete. Annual of the British School at Athens, 19, 35-47.

Hopkinson, N. (1984). Callimachus' Hymn to Zeus. Classical Quarterly, 34, 139-148.

Hopkinson, N. (Ed.). (1994). A Hellenistic Anthology. Cambridge: Cambridge University Press.

Horowski, J. (1967). Folklor w twórczości Kallimacha z Cyreny. Poznań: UAM.

Howell, E. B. (1964). St. Paul and the Greek World. Greece and Rome, 11(1), 7-29.

Hutchinson, R. W. (1963). Prehistoric Crete. Harmondsworth: Penguin Books.

Jones, W. H. S. (1963). Pliny: Natural History (Vol. VIII; Books 28-32). London-Cambridge: Harvard University Press.

Kaczyńska, E. (1997). Kallimach, Epimenides i kreteńska Arkadia [Callimachus, Epimenides and the Cretan Arcadia]. In J. Rostropowicz (Ed.), Studia nad kultura antyczna (pp. 31-40). Opole: Uniwersytet Opolski.

Kaczyńska, E. (1999a). Oronimia kreteńska w twórczości Kallimacha z Cyreny [Cretan oronymy in the poetical works by Callimachus of Cyrene]. Onomastica, 44, 5-28.

Kaczyńska, E. (1999b). The Panacra Mountains in Callimachus and Epimenides. Eos, 86(1), 33-37.

Kaczyńska, E. (2000a). Równina Omfalijska w Kallimachejskim Hymnie do Dzeusa (w. 42-45) [The Omphalian Plain in the Callimachean Hymn to Zeus (1. 42-45)]. Eos, 87(1), 101-111.

Kaczyńska, E. (2000b). Wizerunek Kreteńczyków w twórczości Kallimacha z Cyreny [A presentation of the Cretans in literary works by Callimachus of Cyrene]. Meander, 55(6), 513-535.

Kaczyńska, E. (2002). Il motivo della tomba di Zeus a Creta in Epimenide e Callimaco. Živa Antika, 56(1-2), 83-107.

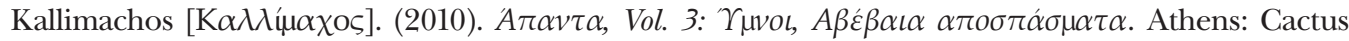
Editions.

Kitchell, K. F. (1977). Topographica Cretica: Topoi of the Classical Crete with Testimonia. Chicago: An unpublished Ph.D. Dissertation.

Kotlińska-Toma, A., \& Żybert-Pruchnicka, E. (Eds.). (2016). Kallimachus. Dzieta poetyckie [Callimachus. Poetical works] (Vol. I: Hymny i epigramy). Wrocław: Instytut Studiów Klasycznych, Śródziemnomorskich i Orientalnych Uniwersytetu Wrocławskiego.

Leclerc, M.-Ch. (1992). Épiménide sans parodoxe. Kernos, 5, 221-233.

Lombardo, S., \& Ross, D. (1988). Callimachus. Hymns, Epigrams, Selected Fragments. Baltimore-London: The Johns Hopkins University Press.

Mair, A. W. (Transl.). (1989). Callimachus, Hymns and Epigrams, Lycophron, Aratus. London-Cambridge: Harvard University Press.

Marinatos, S. (1962). Zur Frage der Grotte von Arkalochori. Kadmos, 1(2), 87-94.

McLennan, G. R. (1977). Callimachus, Hymn to Zeus. Roma: Edizioni dell'Ateneo \& Bizzarri.

Meineke, A. (Ed.). (1992). Stephani Byzantinii Ethnicorum quae supersunt. A Geographical Lexicon on Ancient Cities, Peoples, Tribes and Toponyms. Chicago: Ares Publishers.

Nicklin, T. (1916). Epimenides' Minos. The Classical Review, 30, 33-37.

Oldfather, C. H. (1970). Diodorus of Sicily in twelve volumes (Vol. III). London-Cambridge: Harvard University Press. 
Papathanasopoulos, Th. [П $\alpha \pi \alpha \theta \alpha v \alpha \sigma o ́ \pi o v \lambda o \varsigma, \Theta.] . ~(1996) . ~ K \alpha \lambda \lambda \iota \mu \alpha ́ \alpha o v ~ ' \Upsilon \mu v o \iota$ [Callimachus'

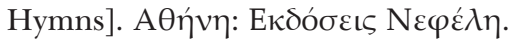

Podbielski, H. (1994). Der Dichter und die Musen im Prooimion der Hesiodeischen Theogonie. Eos, 82, 173-199.

Powell, J. U. (1916). On an Alleged New Fragment of Epimenides. The Classical Review, 30, 139-142. Rendel Harris, J. (1906). The Cretan Always Liars. The Expositor, 2 (Series 7), 305-317.

Rendel Harris, J. (1912). St. Paul and Epimenides. The Expositor, 4 (Series 8), 348-353.

Rutkowski, B., \& Nowicki, K. (1996). The Psychro Cave and Other Sacred Grottoes in Crete. Warsaw: Art and Archaeology.

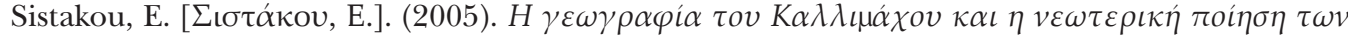

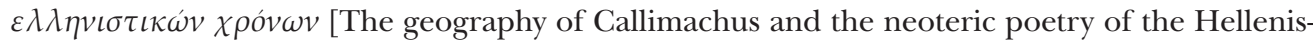

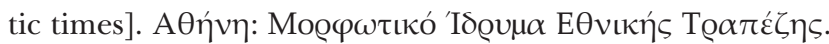

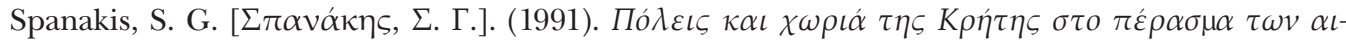

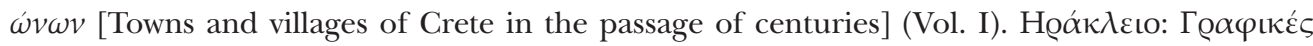

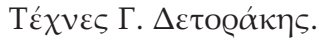

Steffen, W. (1983). De Callimachi hymno in Iovem. In P. Händel, \& W. Meid (Eds.), Festschrift für Robert Muth zum 65. Geburtstag am 1. Januar 1981, dargebracht von Freunden und Kollegen (pp. 469-477). Innsbruck: Institut für Sprachwissenschaft der Universität Innsbruck.

Stephens, S. A. (2015). Callimachus, The Hymns. Oxford-New York: Oxford University Press.

Strataridaki, A. I., Chalkiadakis, E. G., \& Ioannidou, P. K. (2006). Water in Ancient Civilizations: The Case of Ancient Arkadia in Crete. In Transactions of the 1st International Symposium on Water and Wastewater Technologies in Ancient Civilizations (pp. 180-190). Heraklion: International Water Association.

Tandy, D. W. (1979). Callimachus, Hymn to Zeus. Introduction and Commentary. New Haven: Yale University (microfilm; unpublished Ph.D. dissertation).

Vasilakis, A. T. (2000). The 147 Cities of Ancient Crete. Herakleion: Kairatos Editions.

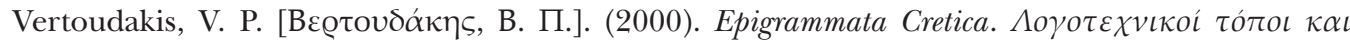

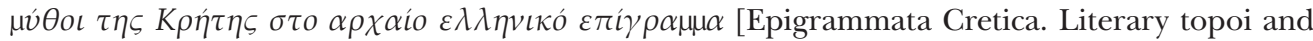

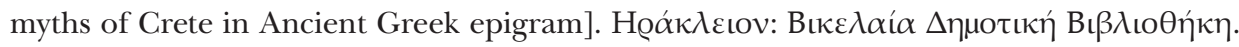

West, M. L. (1983). The Orphic Poems. Oxford-New York: Oxford University Press.

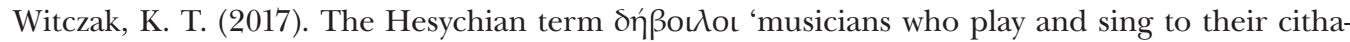
ras'. Symbolae Philologorum Posnaniensium Graecae et Latinae [in press].

Żybert-Pruchnicka, E. (2016). Hymn na Zeusa [Hymn to Zeus]. In A. Kotlińska-Toma, \& E. Żybert-Pruchnicka (Eds.), Kallimachus. Dzieta poetyckie [Callimachus. Poetical works] (Vol. I, pp. 111-113). Wrocław: Instytut Studiów Klasycznych, Śródziemnomorskich i Orientalnych Uniwersytetu Wrocławskiego.

Dr. hab. Prof. Elwira Kaczyńska, Ph.D. / aradaina@gmail.com.

University of Łódź

Faculty of Philology

Chair of Classical Philology

Pomorska 171/173, PL-90-236 Łódź, Poland 
